\title{
Une photographie de Charles Marville
}

\section{Gwénaël Citérin}

\section{(2) OpenEdition}

Journals

Édition électronique

URL : http://journals.openedition.org/rbnu/1566

DOl : $10.4000 /$ rbnu. 1566

ISSN : 2679-6104

\section{Éditeur}

Bibliothèque nationale et universitaire de Strasbourg

\section{Édition imprimée}

Date de publication : 1 mai 2016

Pagination : 100

ISBN : 9782859230623

ISSN : 2109-2761

\section{Référence électronique}

Gwénaël Citérin, «Une photographie de Charles Marville », La Revue de la BNU [En ligne], 13 | 2016, mis en ligne le 01 mars 2020, consulté le 11 décembre 2020. URL : http://journals.openedition.org/rbnu/ 1566 ; DOl : https://doi.org/10.4000/rbnu.1566

\section{(C) $10(0$}

La Revue de la BNU est mise à disposition selon les termes de la Licence Creative Commons Attribution - Pas d'Utilisation Commerciale - Partage dans les Mêmes Conditions 4.0 International. 


\section{NOUVELLES ACQUISITIONS PATRIMONIALES}

\section{Une photographie de Charles Marville}

Charles Marville (1816-1879) reste connu comme le photographe du Paris d'avant les grands travaux haussmanniens, qui modifièrent profondément le visage de la capitale sous le Second Empire. D'abord illustrateur, formé à la gravure et à la lithographie, il dut sa vocation de photographe à sa rencontre avec le calotype. Ce procédé photographique, inventé en 1841 par William Henry Ford Talbot, permettait de reproduire des images positives d'après un négatif, contrairement au daguerréotype. En 1851, Marville s'associa avec Louis-Désiré BlanquartEvrard (1802-1872). Ce dernier, chimiste et négociant en drap, créa à Lille une des premières imprimeries photographiques, qui périclita en 1855 . Marville collabora, en 1853-1854, à l'illustration des albums de Blanquart-Evrard, Les bords du Rhin et L'art religieux. À cette occasion, il prit des vues de la cathédrale de Strasbourg, dont celle qui vient d'entrer dans les collections de la BNU et représente les vertus écrasant les vices, figures du grand portail.

En 1862, Marville fut nommé photographe officiel de la ville de Paris. À ce titre, il se vit confier la mission de fixer pour la postérité le Paris que Napoléon III et le préfet Haussmann allaient reconstruire.

Les négatifs de Marville sur le vieux Paris sont consultables à la Bibliothèque historique de la Ville de Paris. Les vues prises en France,

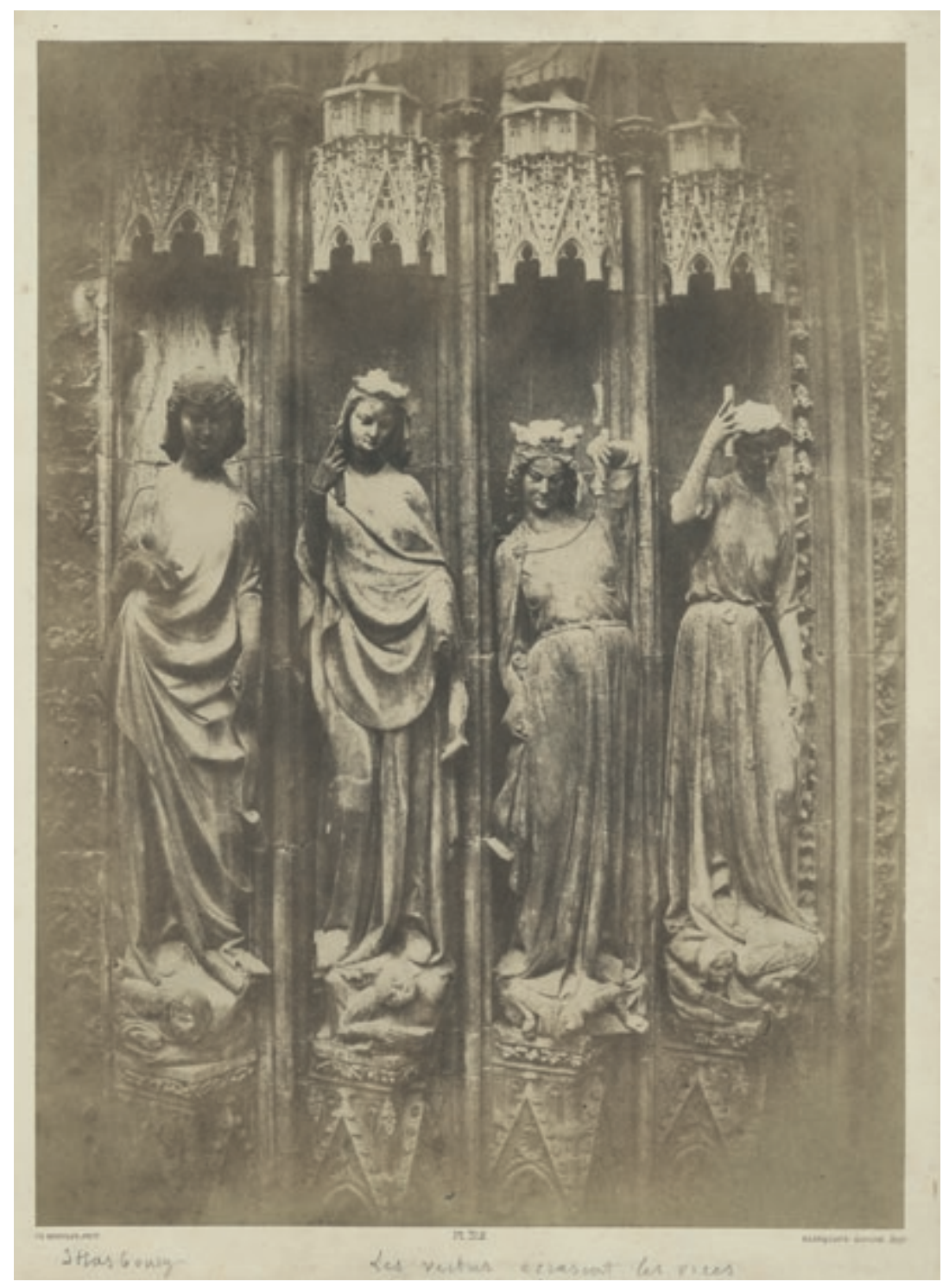

notamment à Strasbourg, sont, quant à elles, conservées aux archives photographiques de la Médiathèque de l'architecture et du patrimoine.

\section{Gwénaël Citérin}

